\title{
Paesaggi urbani tra tradizione e fruizione virtuale: un viaggio tra sperimentazioni di estetica digitale
}

\author{
Alice Palmieri
}

Abstract

Le più recenti innovazioni tecnologiche si offrono già da qualche anno, come strumento per la valorizzazione e la diffusione delle conoscenze del patrimonio culturale. Nella condizione pandemica che stiamo affrontando, alcune di queste tecnologie in particolare consentono una fruizione dello spazio pubblico 'a distanza', quindi in remoto o in una formula di partecipazione outdoor che consente di godere di particolari installazioni urbane, mantenendo la distanza fisica, ormai necessaria. Le tecniche di video-proiezione e di video-mapping, per esempio, rispondono all'ambizione di amplificare il piano della rappresentazione, fino ad arrivare a occupare intere facciate di edifici e monumenti, definendo così delle 'scenografie' digitali. Queste possono raccontare un contenuto legato all'architettura e ai beni culturali coinvolti nella proiezione, oppure possono offrire delle performance artistiche, dal grande impatto emotivo, che propongono rappresentazioni astratte e dinamiche.

II contributo proposto indaga le possibilità espressive e le sperimentazioni di estetica digitale messe in scena negli ultimi mesi del 2020, rivelando nuovi possibili approcci ai concetti di fruizione e di accessibilità, intesi in un senso ampio e contemporaneo, che mira a ridurre le distanze attraverso l'impiego di nuovi linguaggi e tecnologie.

\section{Parole chiave}

video-proiezioni, video-mapping, percezione, tecnologie, sperimentazioni digitali.

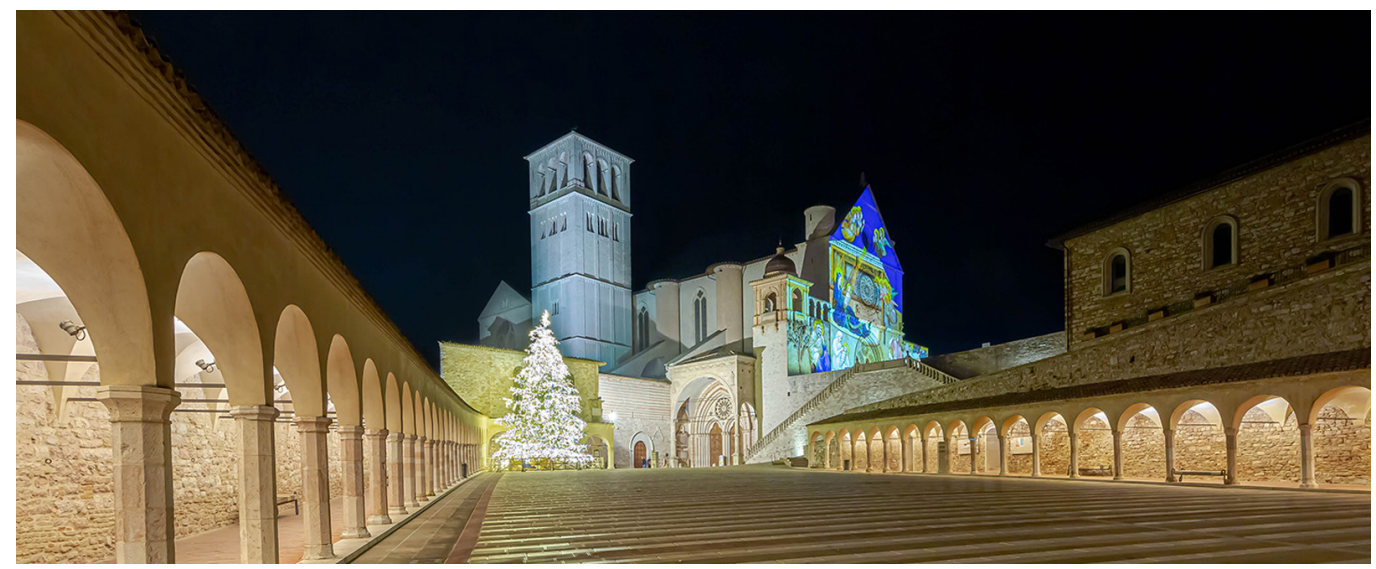




\section{Introduzione}

I processi di costruzione di uno spazio virtuale tengono insieme questioni inerenti due aspetti: la simulazione (e quindi la percezione) e le tecniche costruttive (quindi la geometria) [De Rubertis 200 I, p. 8]. II binomio geometria-percezione non è nuovo all'ambito della rappresentazione e pone interessanti riflessioni sulle relazioni e sui parallelismi dati dai criteri di visione e quelli di proiezione. In entrambi i casi, infatti, esiste un centro (di vista o di proiezione), una direzione e un piano (o quadro). Oggetto della riflessione che si va proponendo è proprio il piano, la superficie su cui prende forma il disegno, e la possibilità di poter ampliare sempre più l'estensione della rappresentazione, invadendo lo spazio reale.

In sintesi, questo è l'obiettivo delle tecniche di video-proiezione e di video-mapping, frutto di una serie di ricerche che si basano sull'utopia (concretizzabile) che si possa fuoriuscire da una cornice rigida, e nel $X X \mid$ secolo è arrivata la consapevolezza di poter espandere lo spazio, integrando la virtualità alla realtà concreta, aumentandola [Maniello 20|4, p. 7]. Si tratta di mettere in pratica quell'obiettivo che si erano posti i futuristi nel Manifesto tecnico della Pittura del I9 I2, ovvero "porremo lo spettatore al centro del quadro", operazione oggi possibile grazie alle prestazioni delle nuove tecnologie. II video mapping rientra infatti nel settore della realtà aumentata e costituisce quella sezione di interessanti applicazioni che riguardano la 'medializzazione' del contesto urbano, dove sono proposte nuove e multiple relazioni tra città e individuo. Per alcune di queste si tratta di scenografiche performance artistiche, tra installazioni e narrazioni, dove l'ambiente non è più lo sfondo, ma diviene l'opera stessa [lppoliti, Meschini 2010, p. 80].

Prendono così forma degli spazi urbani 'illuminati', digitalizzati e fruibili, anche nelle ore serali, in cui i soggetti esplorano ambienti reali, che risultano però trasformati da una temporanea ed effimera sovrapposizione di elementi virtuali. II fulcro della rappresentazione diventa quindi l'esperienza percettiva, in cui lo spettatore è anche fruitore dello spazio pubblico ed è coinvolto in una performance emozionale in cui le proiezioni trasformano le facciate degli edifici, rendendoli strumenti di narrazione. I prospetti urbani non sono quindi l'oggetto del racconto, ma il piano su cui i contenuti digitali vengono perfettamente conformati, dando nuove sembianze alla scena architettonica [Ippoliti, Meschini 2010, p. 80]. Queste

Fig. I. Installazione di rappresenta il monologo de I/ Grande Dittatore di Charlie Chaplin, nell'ambito dell'evento Pensieri Illuminati, Milano 31/12/2020 (@) Felice Reserved)

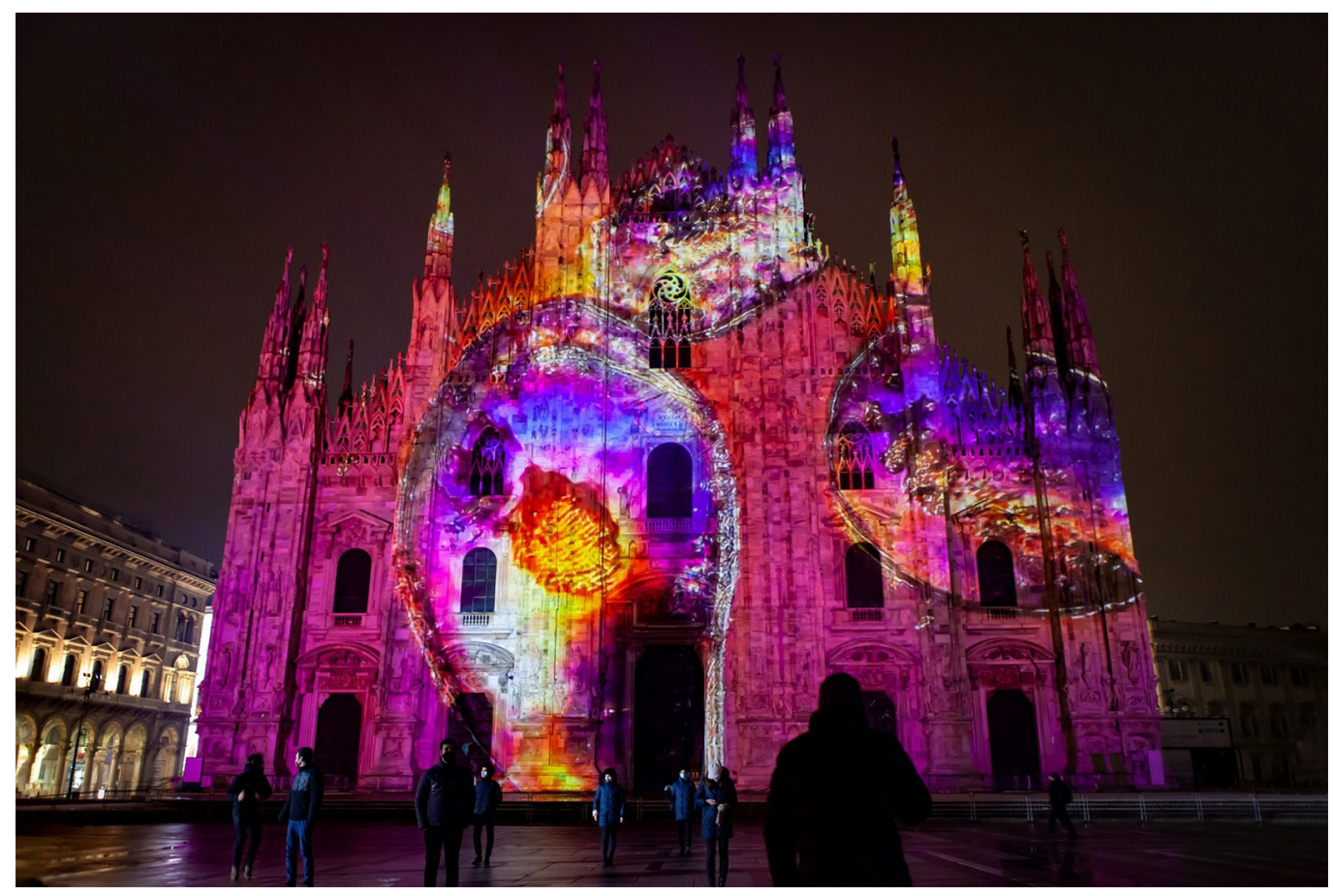



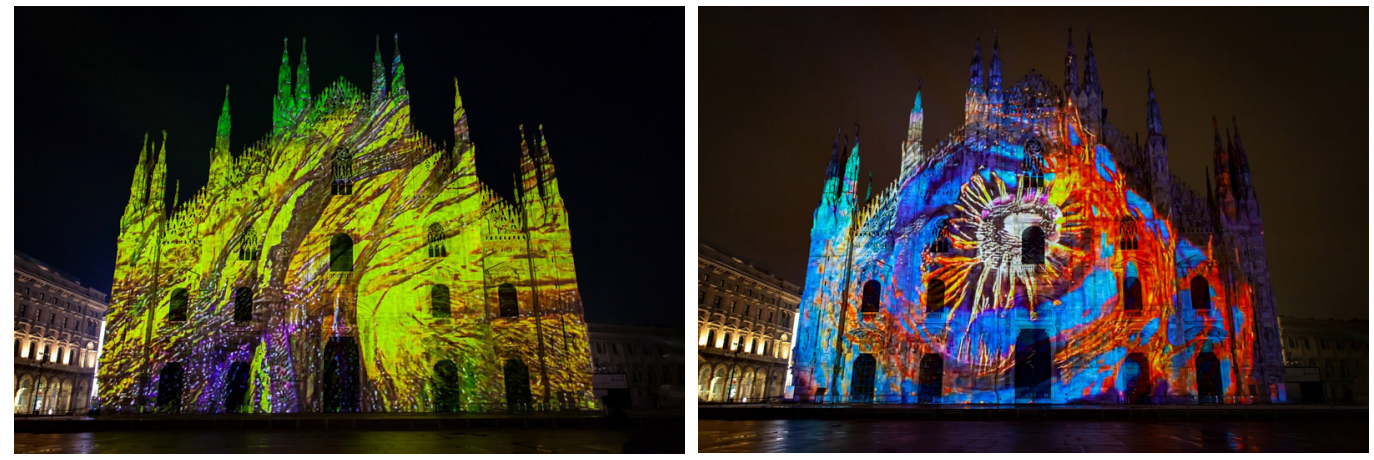

sorprendenti istallazioni generano un immersivo coinvolgimento sensoriale ed empatico, che migliora la comunicazione, la memoria dell'esperienza e l'elaborazione dei contenuti, qualificandosi così come un efficace strumento di valorizzazione del patrimonio culturale (talvolta immateriale) e architettonico.

Si definiscono in questo modo le condizioni affinché trovino espressione forme comunicative sempre più efficaci e contemporanee, che puntando all'esperienza, emotiva e cognitiva, e alla partecipazione del pubblico, riescano ad avvicinare un numero sempre maggiore di utenti. Tecnologie digitali, dunque, per comunicare contenuti culturali attraverso modelli comunicativi essenzialmente visuali che consentano di agire attraverso la memoria delle emozioni e il tempo del racconto [lppoliti 20I I, p. 9]. Naturalmente i soggetti narrativi possono variare a seconda del contesto (fisico e temporale), delle richieste della committenza e della produzione, che mette in scena i racconti in base alla propria conoscenza della storia delle immagini, alla ricerca e alla sensibilità personale.

Da un punto di vista prettamente esecutivo, è noto come nella tecnica del video-mapping sia necessario produrre un contenuto digitale perfettamente sincrono all'ambiente, sul e nel quale si proietta. La prima operazione pertanto riguarda la mappatura della superficie 'ospitante', che con le prime fasi di analisi, racconta qualcosa di sé e della sua storia. Non in tutte le installazioni di video proiezione in AR però, le narrazioni parlano del contesto o della storia dell'architettura che si offre come supporto; talvolta le elaborazioni grafiche sono astratte, oppure riguardano temi specifici, (di attualità, per esempio, come vedremo nell'intervento milanese) e non partono dalla mappatura della superficie di proiezione, ma in ogni caso la sintesi tra arte e comunicazione a scala urbana, ha come fulcro l'architettura e il suo contesto spaziale.

\section{Sperimentazioni di estetica digitale}

Già da qualche anno, le nuove tecnologie appartengono al nostro vivere quotidiano e alle nostre attività lavorative, fino a ritrovarsi protagoniste in questo drammatico 2020, che ha completamente stravolto qualsiasi routine. I dispositivi digitali sono ormai il principale strumento di connessione con il mondo esterno, spesso fisicamente irraggiungibile. Un piccolo risvolto positivo però, si è potuto riscontrare nel complesso rapporto con i dispositivi digitali, ed è dato da una maggiore apertura del pubblico a considerare le tecnologie, non più solo come strumenti per trasmettere ed elaborare dati, ma come valide e inesauribili fonti di espressione e creatività. Ancora una volta la condizione pandemica ci mette alla prova e stimola l'elaborazione di forme artistiche 'a distanza', capaci di creare relazioni virtuali con l'arte e con i luoghi lontani. Nel 2020 sono state allestite alcune azioni creative che hanno coinvolto il pubblico attraverso la partecipazione in remoto e la fruizione outdoor, per rispondere alle esigenze di questo tempo e prendere parte al cambiamento culturale che si sta delineando.

Tra queste esperienze, virtuali e interdisciplinari, si colloca il progetto realizzato da Felice Limosani, artista riconosciuto in ambito internazionale, interprete e innovatore delle Digi- 
Figg. 4, 5. La Basilica di vetro. Installazione realizzata da

Marco Capasso -

Studio Creativo.

Rapresentazione de

Rappresentazione de

Cantico delle Creature.

<www.sanfrancesco.org

consultato il 28 febbraio 202I)
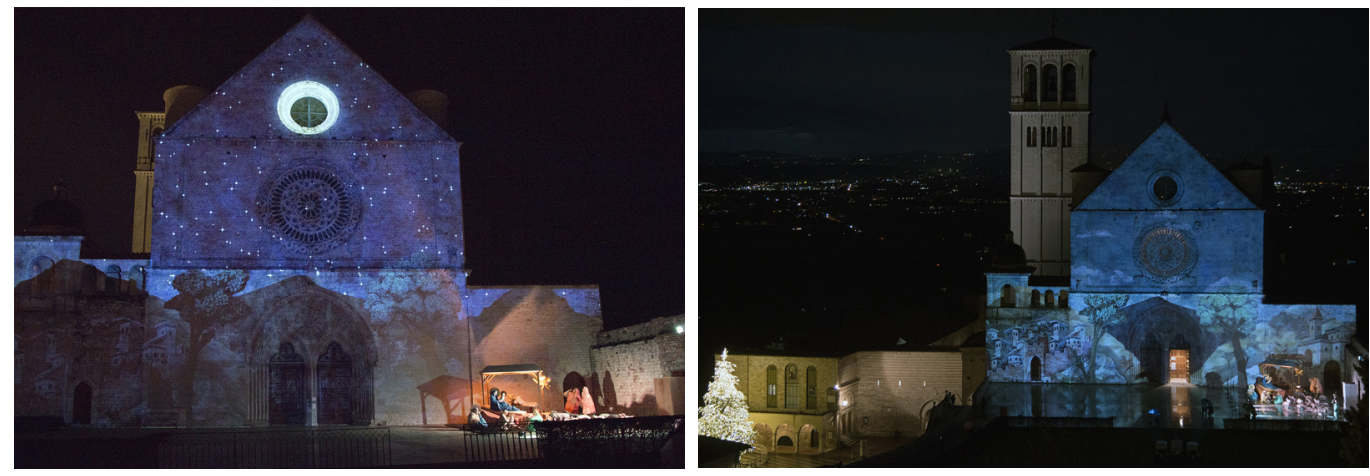

tal Humanities, in collaborazione con Beatrice Venezi, direttrice d'orchestra. Dall'incontro dei due, è nato un progetto che integra musica, discipline umanistiche e cultura digitale, per sperimentare un nuovo livello di percezione, di conoscenza e di interazione tra persone, tecnologie ed esperienze sinestetiche. L'occasione è stata offerta da una commissione del Comune di Milano per il capodanno, che ha segnato il passaggio da un 2020 carico di difficoltà, a un 202 I pieno di speranze. Per questo, la proposta degli artisti ha voluto mettere in piedi una serata d'arte e musica di grande suggestione, grazie a un progetto artistico multimediale ideato per una visione in streaming dalle proprie case, nel pieno rispetto delle restrizioni causate dalla pandemia. Un progetto che permette a tutti di partecipare a distanza. II risultato finale è stata una narrazione collettiva, trasformata dall'artista Felice Limosani in grafica generativa e pixel luminosi, prodotti per essere proiettati come forme, colori e movimenti, sulla facciata principale del Duomo. Un'esperienza resa unica dalla musica diretta dal maestro Beatrice Venezi, eseguita dell'Orchestra I Pomeriggi Musicali e dalla drammaturgia messa in scena dalla Civica Scuola di Teatro Paolo Grassi, Fondazione Milano.

L'aspetto più interessante, dal punto di vista della rappresentazione, è la tecnica ideata da Limosani che prevede di partire dai "pensieri illuminati", quindi da brevi testi inviati spontaneamente dai cittadini in rete e le cui parole sono state frammentate in singole lettere e queste convertite in codici numerici mediante il linguaggio ASCII (Codice Standard Americano per lo Scambio di Informazioni). I numeri ottenuti sono stati inseriti nel motore grafico Unity come parametri generativi, da cui è stato possibile sviluppare contenuti interattivi e animazioni 3D in tempo reale. L'output finale è una grafica generativa astratta che si attiene, per movimenti e cromatismi, a una programmazione specifica con finalità estetiche e artistiche.

L'interazione musicale dell'orchestra ha reso la performance pienamente multisensoriale e dal forte coinvolgimento empatico, riducendo la distanza fisica grazie a un'opera d'arte che è totale metafora di condivisione e rinascita e che, in qualche modo, ha riempito la deserta piazza del Duomo, usualmente punto di incontro e ritrovo durante le festività.

In questo caso l'oggetto della narrazione è dato dalla trasformazione dei 'pensieri illuminati' inviati dal pubblico: si tratta di un'astrazione fortemente emotiva che restituisce una rappresentazione cromatica e dinamica di diversi contenuti individuali, accumunati dal tema della pandemia.

Esistono però, anche installazioni fortemente figurative, in cui lo storytelling è generato dall'architettura che lo ospita e il racconto dà un nuovo senso allo spazio concreto ordinariamente visibile. L'azione di comunicazione mira quindi ad amplificare il messaggio già insito nell'architettura stessa e a metterne in mostra le principali caratteristiche materiche, formali e artistiche.

A quest'ultima casistica appartiene l'installazione urbana realizzata tra Natale e Capodanno 2020 ad Assisi, in una concatenazione di episodi di video-proiezione diffusi tra i siti più significativi della città umbra, nota per essere il luogo di nascita di san Francesco, patrono d'Italia e ideatore della prima rappresentazione della Natività. Ed è proprio questo episodio della cristianità quello che ancora oggi è raccontato, in diverse declinazioni, che hanno origine da 
Fig. 6. La Basilica di vetro. Riproduzione della navata interna con gli affreschi di Giotto.

$<$ www.sanfrancesco.org> (consultato il 28 febbraio 2021)

Fig. 07. La Basilica di vetro. Riproduzione della Natività di Giotto. <www.sanfrancesco.org> (consultato il 28 febbraio 2021)

Fig. 8. Installazione per la Cattedrale di San Rufino, riproduzion dell'Annunciazione a Maria < http $/$. a Maria. <http:// www.comune.assisi. pg.tt/2020/12/0

(consultato il 10 maggio 2021)
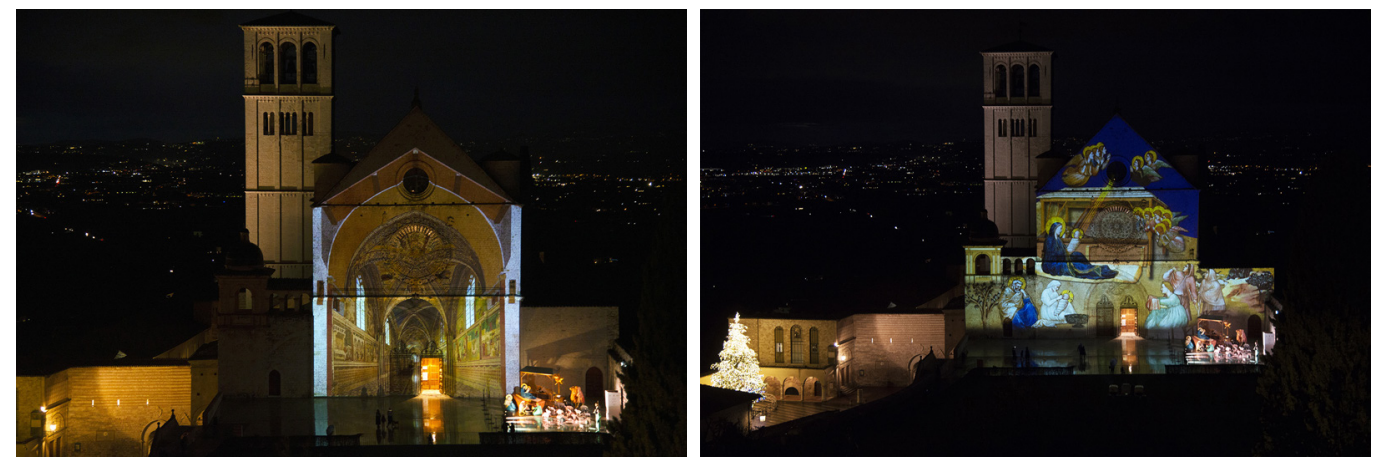

quel primo presepe realizzato da san Francesco a Greccio nel 1223 e che ha dato origine a una tradizione diffusa in tutto il mondo. L'installazione, inaugurata l'8 dicembre 2020, è costituita da dieci mila metri quadri di videoproiezioni che ripropongo gli affreschi di Giotto e che percorrono le strade e le piazze di Assisi per trasformarla in un 'presepe diffuso'. Sotto la direzione artistica dell'architetto Mario Cucinella, l'evento II Natale di Francesco racconta in un modo molto contemporaneo la città e il tempo del Natale, impiegando tecnologie adatte a una fruizione outdoor, più facilmente conciliabile con le esigenze dettate dal distanziamento.

L'installazione coinvolge diversi monumenti rilevanti di Assisi, tra cui la facciata e il campanile della Cattedrale di San Rufino, interessati da un video mapping architetturale e scenografico, che riproduce l'Annunciazione a Maria. II percorso si disegna come un itinerario di stelle luminose, ispirate agli affreschi delle volte della Basilica Inferiore, e che in realtà trasforma Assisi in un'unica grande installazione di luce, visibile anche dalla valle di Santa Maria degli Angeli. Ideato inizialmente come un appuntamento fisico per coinvolgere

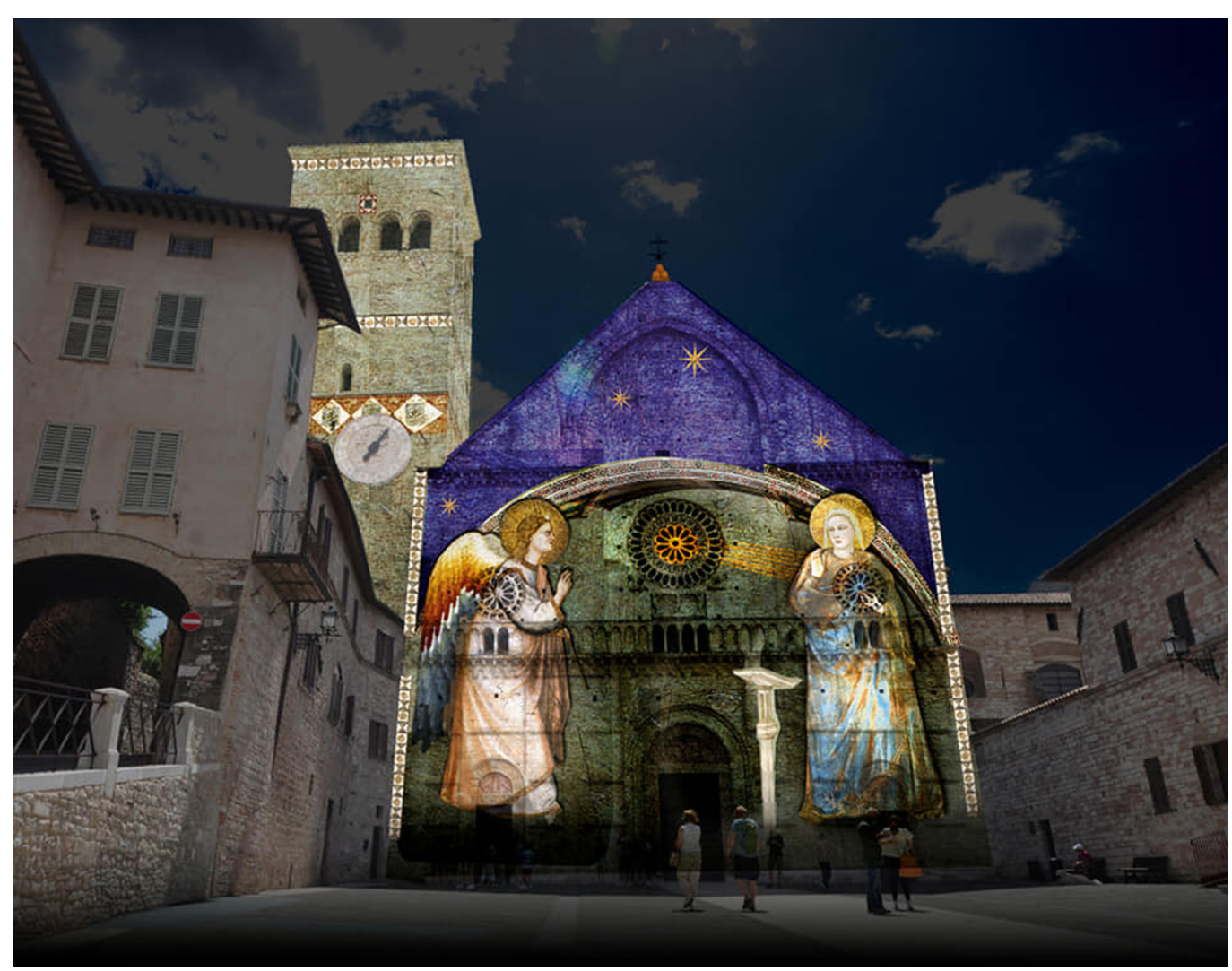


visitatori da ogni parte del mondo, il progetto si è adattato a una nuova formula fondata sulla partecipazione virtuale, in privilegiata presenza per i cittadini umbri, e da remoto per tutti coloro che hanno voluto seguire lo streaming dell'inaugurazione e, in seguito, la riproduzione video via web.

La centralità dell'opera è data dal prospetto della Basilica Superiore, per la quale Marco Capasso - Studio Creativo ha curato e prodotto la Basilica di vetro. L'architetto Capasso ha realizzato quella che lui stesso definisce "un'istallazione di luce additiva" che apre a un racconto, nel cui prologo, ispirato al Cantico delle Creature, frate Sole e sora Luna diventano protagonisti della proiezione, in un'animazione che si dispiega sulla Basilica, facendola quasi sparire nel cielo notturno di fondo. Segue una sequenza di immagini e un incipit evocativo, in cui la luce è protagonista e mostra due antichi argani in movimento, rappresentazione del cantiere medievale che innalza l'impalcatura e costruisce i contorni del prospetto della Basilica. Una geometrizzazione dello spazio, un disegno di linee nette ed essenziali, che dietro l'impalcatura riproduce la facciata con il portale, le cornici e i rosoni, in una riproduzione bianco su nero di straordinaria forza. Poi per qualche istante una luce mostra nuovamente la facciata in pietra, con le sue trame e la sua matericità, per sparire dopo poco, lasciando spazio a una nuova rappresentazione, questa volta prospettica, che svela la struttura interna della navata, definita da un unico spazio scandito dai pilastri e sormontato da volte a crociera. Questo aspetto mostra la magistrale ricostruzione tridimensionale prodotta dall'architetto Capasso, che ha tenuto insieme il modello 3D e le fotografie (ad altissima risoluzione) degli affreschi di Giotto che caratterizzano le pareti interne. Conclusione della proiezione è infatti la riproduzione della Natività di Giotto, tema centrale di tutto l'evento.

Nel caso di Assisi quindi, il soggetto della narrazione è l'architettura, non solo nei suoi spazi esterni, ma anche nella conformazione interna, nei dettagli spaziali e cromatici. Questa sperimentazione digitale apre a una nuova possibilità di fruizione che, in determinate condizioni, consente di scoprire gli ambienti interni dei monumenti, laddove non siano fisicamente accessibili, approcciando così a un concetto di 'accessibilità' ampio e contemporaneo, che mira a ridurre le distanze attraverso l'uso di nuovi linguaggi.

\section{Conclusioni}

Le recenti esperienze descritte in questo contributo, mostrano come nel campo della comunicazione visiva, che oggi raccoglie molteplici espressioni del disegno, possano confluire esigenze diverse, che danno esito a variegate soluzioni grafiche: in alcuni casi c'è la necessità di lasciare spazio all'immaginazione dei fruitori e quindi la comunicazione è allusiva e ricerca un impatto emotivo, più che cognitivo; in altri casi invece il fine dell'operazione è divulgativo e mira a rendere accessibili dei contenuti culturali, pertanto si serve di una rappresentazione definita, non soggetta a personali interpretazioni. Queste, in sintesi, sono le condizioni che presentano le sperimentazioni proposte, entrambe accumunate dalla capacità di realizzare 'messe in scena' pubbliche, che coinvolgano spazi urbani e luoghi di culto, creando una narrazione dal grande impatto emotivo e sfruttando nuovi linguaggi e nuove possibilità espressive. Le innovazioni tecnologiche, inoltre, si offrono quale strumento di diffusione della conoscenza del patrimonio culturale e, in particolare attraverso le video-proiezioni e il video mapping, è possibile ampliare il raggio d'azione, raggiungendo diverse categorie di utenti, anche meno inclini all'uso di dispositivi e visori multimediali. Questa modalità di approccio, fisica e digitale insieme, si va costituendo di fatto come un valore aggiunto alla comunicazione e alla fruizione pubblica, anche a distanza.

\section{Ringraziamenti}

Ringrazio Felice Limosani, per la preziosa collaborazione e la passione con cui mi ha descritto il suo lavoro. Si ringraziano l'arch. Marco Capasso, per la disponibilità dimostrata nel racconto del progetto e nella concessione del materiale, e il Convento di San Francesco, in particolare Alessio Maria Antonielli, per aver condiviso la documentazione fotografica. 


\section{Riferimenti bibliografici}

Antonelli E., Mordenti A. (20 I I). La videoproiezione architetturale. Architectural Video projection. In Disegnarecon, vol. 4, n. 8 , Cultural Heritage communication technology, pp. 25-38.

De Rubertis R., Clemente M. (200I). Percezione e comunicazione visiva dell'architettura. Roma: Officina Edizioni.

Di Natale I., Palmieri A. (2015). Tecno-comunicazione creativa. Proiezioni digitali per definire nuovi scenari del patrimonio culturale. In Agribusiness Paesaggio \& Ambiente on line, vol. XVIII, pp. 78-85.

Ippoliti E. (20I I). Media digitali per il godimento del patrimonio culturale. Digital Media and enjoyment of Cultural Heritage. In Disegnarecon, vol. 4, n. 8, Cultural Heritage communication technology, pp. 2-I3.

ppoliti E., Meschini A. (20|0). Dal "modello 3D" alla "scena 3D". Prospettive e opportunità per la valorizzazione del patrimonio culturale architettonico e urbano. / From the "3D model" to the "3D scene". Prospects and opportunities for the enhancement of an architectural and urban cultural heritage. In Disegnarecon, vol. 3, n. 6, Cultural heritage documentation, pp. 77-91.

Maniello D. (20|4). Realtà aumentata in spazi pubblici. Tecniche base di video mapping. Potenza: Le Penseur edizioni.

Rocchi G. (1982). La basilica di San Francesco ad Assisi: interpretazione e rilievo. Firenze: Sansoni Editore.

\section{Sitografia}

<https://www.felicelimosani.com/it/> (consultato il 10 febbraio 2021).

<https://www.felicelimosani.com/it/projects.70/il-grande-dittatore-re-work> (consultato il I0 febbraio 202 I).

<https://www.marcocapasso.it/portfolio/enel-assisi-il-natale-di-francesco/> (consultato il I3 gennaio 202 I).

<https://www.mcarchitects.it/project/il-natale-di-francesco> (consultato il I3 gennaio 202 I).

$<$ https://www.sanfrancescopatronoditalia.it/notizie/eventi/assisi-citt\%C3\%A0-presepe-da-oggi-rivivono-gli-affreschi-di-giotto-50242> (consultato il 24 gennaio 202I)

<https://www.sanfrancescopatronoditalia.it/notizie/eventi/enel-illumina-assisi-con-il-natale-di-francesco-5030| > (consultato il 24 gennaio 2021)

\section{Autore}

Alice Palmieri, Università della Campania ‘Luigi Vanvitelli', alice.palmieri@unicampania.it

Per citare questo capitolo: Palmieri Alice (2021). Paesaggi urbani tra tradizione e fruizione virtuale: un viaggio tra sperimentazioni di estetica digitale/Urban Landscapes between Tradition and Virtual Fruition: a Journey through Experiments in Digital Aesthetics. In Arena A. Arena M. Mediati D. Raffa P (a cura di). Connettere Un disegno per annodare e tessere Lingugagi Distanze Tecnologie. Atti del $42^{\circ}$ Convegno Internazionale 42th International Conference of Representation Disciplines Teachers. Milano: FrancoAngeli, pp. 2535-2548. 


\title{
Urban Landscapes between Tradition and Virtual Fruition: a Journey through Experiments in Digital Aesthetics
}

\author{
Alice Palmieri
}

Abstract

For some years now, the latest technological innovations have been a tool for expanding and sharing knowledge about cultural heritage. In the pandemic condition we are facing, some of these technologies allow a fruition of the public space 'distancing', remotely or in a formula of 'outdoor' participation that allows the enjoyment of particular urban installations, while maintaining the physical distance that is now necessary. The technique of video-projection and video-mapping, for example, responds to the ambition to amplify the surface of the representation, to the point of occupying entire facades of buildings and monuments, thus defining digital 'sets'. These can narrate a content related to the architecture and cultural heritage involved in the projection, or they can offer artistic performances, with great emotional impact, that propose abstract and dynamic drawings.

This paper investigates the expressive possibilities and experiments in digital aesthetics staged in the last months of the 2020s, thus revealing possible new approaches to the concepts of fruition and accessibility, understood in a wide and contemporary sense, which aims to reduce distances through the use of new languages and technologies.

Keywords

video-projections, video-mapping, perception, technologies, digital experiments.

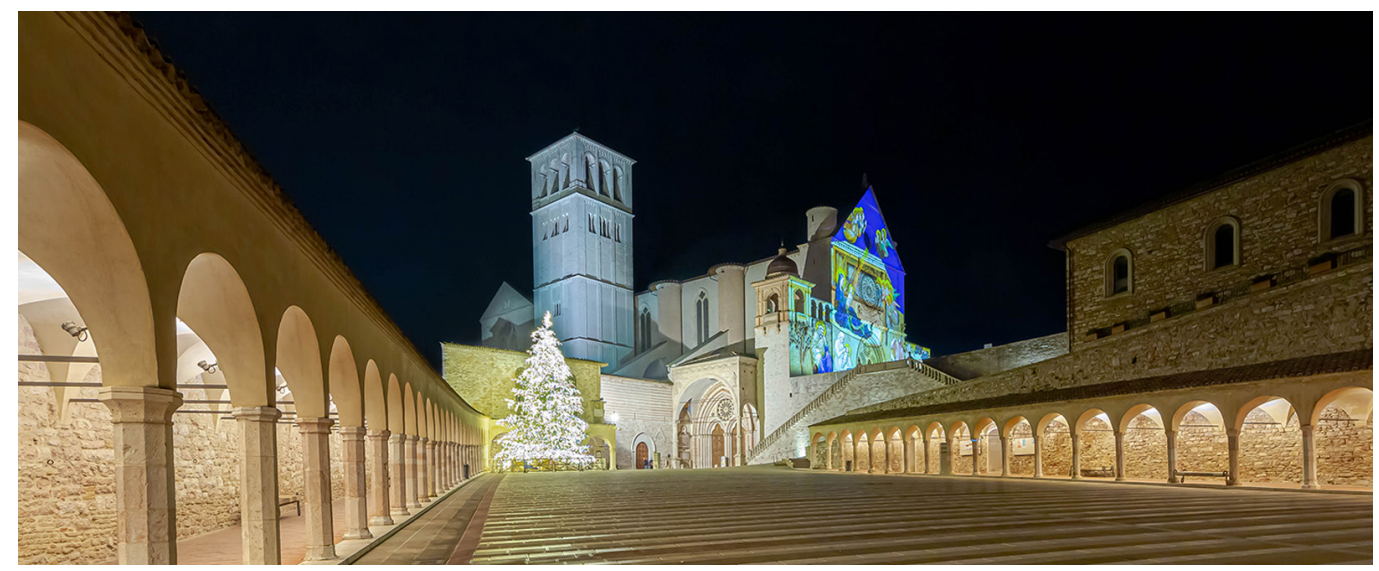




\section{Introduction}

The processes of construction of a virtual space, hold together issues concerning two aspects: simulation (and therefore perception) and construction techniques (therefore geometry) [De Rubertis 200I, p. 8]. The binomial geometry-perception is not new to the field of representation and poses interesting reflections on the relations and parallels given by the criteria of vision and those of projection. In both cases there is in fact a centre (of view or of projection), a direction and a plane (or framework). The object of this reflection is precisely the plane, therefore the surface on which the drawing takes shape, and the possibility of being able to expand the extension of the representation by invading real space. In essence, this is the aim of the video mapping technique, which is the culmination of a series of researches based on the (realisable) utopia that we can escape from a rigid frame, and in the $2 I^{\text {th }}$ century we have realised that it is possible to expand space, integrating virtuality with concrete reality, augmenting it [Maniello 20 I4, p. 7]. It is a matter of putting into practice the objective that the Futurists had set themselves in the Technical Manifesto of Painting of 1912, that is " to place the spectator at the centre of the painting", an operation that is now possible thanks to the performance of new technologies. In fact, video mapping falls within the field of augmented reality and constitutes that section of interesting applications that concern the 'medialisation' of the urban context, where new and multiple relationships between the city and the individual are proposed. Some of these are scenic artistic performances, between installations and narrations, where the environment is no longer the background, but becomes the work itself [lppoliti, Meschini 2010, p. 80].

Thus 'illuminated' urban spaces take shape, digitised and available, even in the evening hours, in which the subjects explore real environments, which are however transformed by a temporary and ephemeral overlapping of virtual elements. The focus of the representation becomes the perceptive experience, in which the spectator is also a user of the public space and is involved in an emotional performance in which the projections transform the facades of the buildings, making them instruments of narration. The urban facades are therefore not the subject of the story, but the plane on which the digital contents are perfectly shaped, giving new semblances to the architectural scene [lppoliti, Meschini 20 I0, p. 80].These surprising installations generate an immersive sensory and empathic involvement, which improves

Fig. I. Installation by Felice Limosani, created with the monologue from Charlie Chaplin's The Great Dictator, as part of the event Pensieri llluminati, Milan 31/12/2020 (C) Felice Limosani. All Rights Reserved)

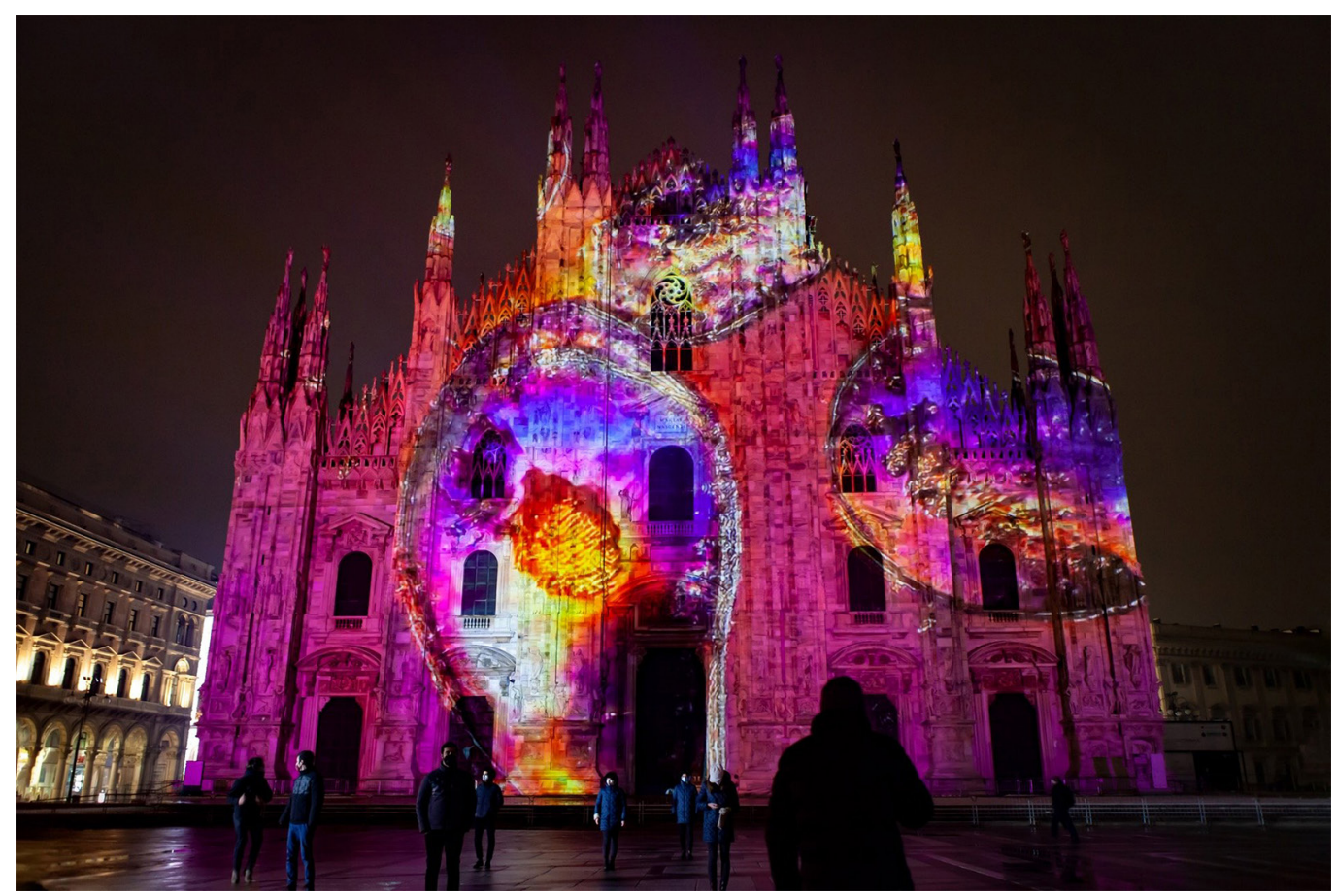



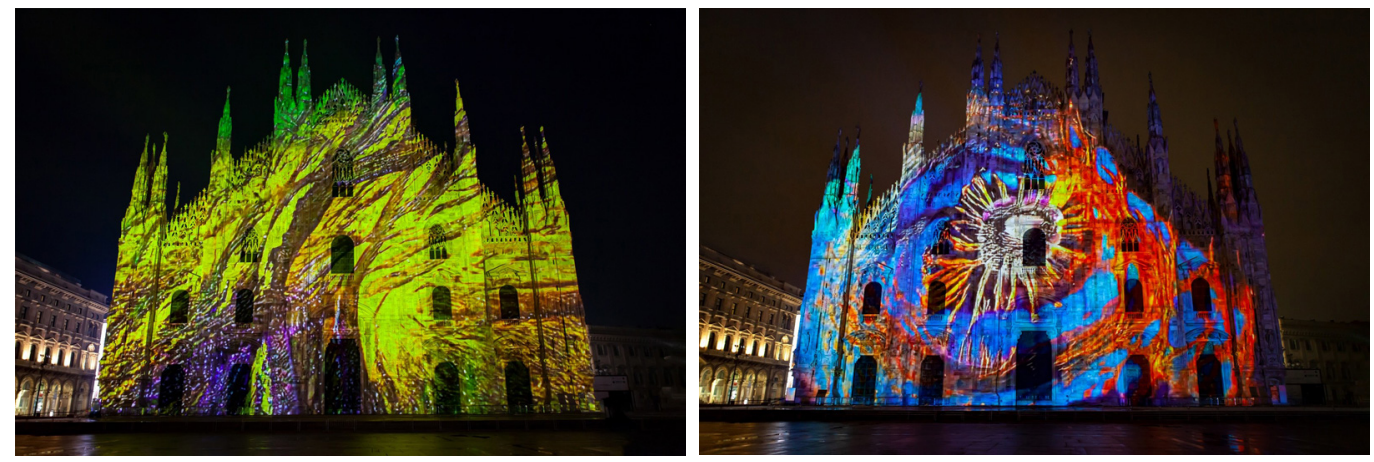

communication, memory and elaboration of the contents, thus qualifying as an effective tool for the enhancement of cultural and architectural heritage.

In this way, the conditions are defined so that more and more effective and contemporary forms of communication can find expression, aiming at the emotional and cognitive experience, and at the participation of the public, succeeding in attracting an increasing number of users. Digital technologies, therefore, to communicate cultural content through essentially visual communication models that allow to act through the memory of emotions and the time of the story [lppoliti 201 I, p. 9].

Of course, the narrative subjects can vary depending on the context (physical and tempo$\mathrm{ral}$ ), the demands of the client and the production, which stages the stories according to its knowledge of the history of images, research and personal sensitivity.

From a purely executive point of view, it is well known that in the video mapping technique it is necessary to produce a digital content perfectly synchronous with the environment, on and in which it is projected. The first operation therefore concerns the mapping of the 'host' surface, which, with the first phases of analysis, tells something about itself and its history. Not in all AR video projection installations, however, do the narratives speak of the context or history of the architecture offered as support; sometimes the graphic elaborations are abstract, or concern specific themes (current affairs, for example, as we shall see in the Milan intervention), but in any case, the synthesis between art and communication on an urban scale always has architecture and its spatial context as its focus.

\section{Digital aesthetics experiments}

For some years now, new technologies have been a part of our daily lives and work activities, to the extent that they are now the protagonists of this dramatic 2020, which has completely overturned any routine. Digital devices are now the main means of connecting with the outside world, which is often physically unreachable. A small positive aspect, however, could be found in the complex relationship with digital devices, and it is given by a greater openness to consider technologies not only as tools for transmitting and processing data, but as valid and inexhaustible sources of expression and creativity. Once again, the pandemic condition challenges us and stimulates the development of artistic forms 'at a distance', capable of creating virtual relations with art and with distant places. In 2020 a number of creative actions were staged, involving the public through remote participation and 'outdoor' enjoyment, to respond to the needs of this time and take part in the cultural change that is taking shape.

Among these virtual and interdisciplinary experiences is the project by Felice Limosani, an internationally recognised artist, interpreter and innovator of the Digital Humanities, together with Beatrice Venezi, an orchestra conductor. Their encounter has resulted in a project that integrates music, the humanities and digital culture to experiment with a new level of perception, knowledge and interaction between people, technologies 
Figs. 4, 5. La Basilica di vetro. Installation by Marco Capasso - Studio Creativo - Canticle of the Creatures. < www. sanfrancesco.org $>$

(consultato il 28 febbraio 2021)
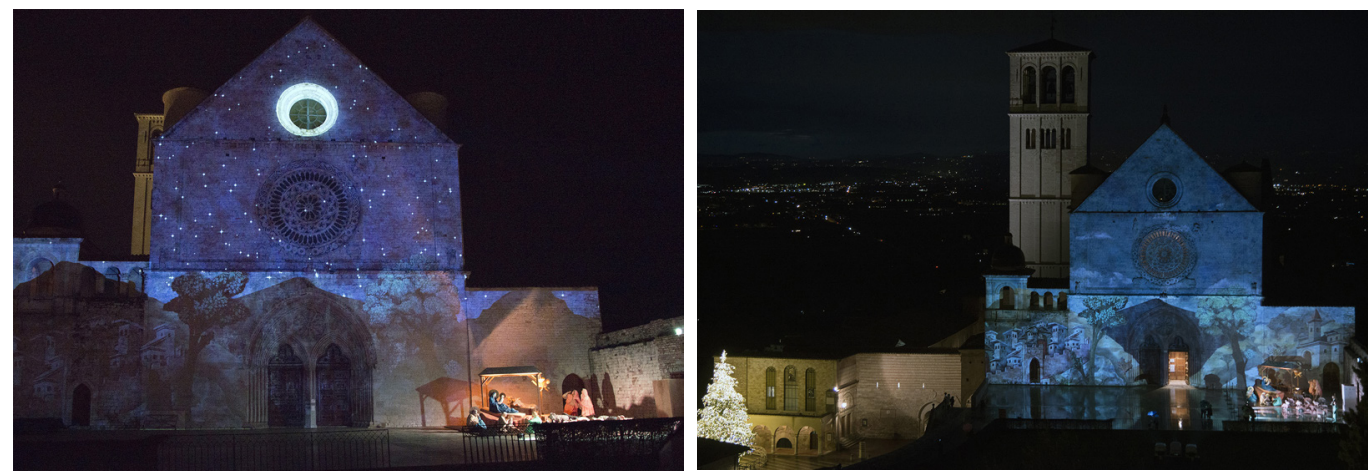

and synesthetic experiences. The occasion was offered by a commission of the Milan Municipality for New Year's celebration, which marked the transition from a 2020 full of difficulties, to a 2021 full of hope. For this reason, the artists' proposal was to set up a highly suggestive evening of art and music, thanks to a multimedia art project designed for streaming from one's home, in full compliance with the restrictions caused by the pandemic. A project that allows everyone to participate from a distance. The final result was a collective narrative, transformed by artist Felice Limosani into generative graphics and luminous pixels, produced to be projected as shapes, colours and movements, on the main façade of the Duomo. An experience made unique by the music conducted by Maestro Beatrice Venezi, performed by the Orchestra I Pomeriggi Musicali and the dramaturgy staged by the Civica Scuola di Teatro Paolo Grassi - Fondazione Milano. The most interesting aspect, from the point of view of representation, is the technique devised by Limosani, which involves starting from 'enlightened thoughts', then from short texts sent spontaneously by citizens on the web and whose letters have been converted using the ASCII language (Standard American Code for Information Exchange). The numbers obtained were fed into a graphics engine as generative parameters, from which it was possible to develop interactive content and 3D animations in real time. The final output is an abstract generative graphic that follows, for movements and colours, a specific programming with aesthetic and artistic purposes. The musical interaction of the orchestra made the performance fully multisensory and with a strong empathic involvement, reducing the physical distance thanks to a work of art that is a total metaphor for sharing and rebirth and that, in a way, filled the deserted Piazza del Duomo, usually a meeting point during the festivities.

In this case the subject of the narration is the transformation of the 'illuminated thoughts' sent by the public: it is a strongly emotional abstraction that returns a chromatic and dynamic representation of different individual contents, united by the theme of the pandemic. There are also highly figurative installations, in which the storytelling is generated by the architecture that hosts it and the tale gives new meaning to the ordinarily visible concrete space. The communication action thus aims to amplify the message already inherent in the architecture itself and to showcase its main material, formal and artistic characteristics.

The urban installation realised between Christmas and New Year's Day 2020 in Assisi belongs to the latter case, in a concatenation of video-projection episodes spread among the most significant sites of the Umbrian city, known for being the birthplace of Saint Francis, patron saint of Italy and creator of the first representation of the Nativity. And it is precisely this episode of christianity that is still recounted today, in various versions, which originate from that first nativity scene created by Saint Francis in Greccio in 1223 and which gave rise to a tradition that has spread all over the world. The installation, which will be inaugurated on 8 December 2020, consists of ten thousand square metres of video projections reproducing Giotto's frescoes and running through the streets and squares of Assisi, transforming it into a "widespread nativity scene". Under the artistic direction of architect Mario Cucinella, the event II Natale di Francesco tells the story of the city and the Christmas season in a very contemporary way, using 
Fig. 6. La Basilica di vetro. Reproduction of the interior nave with Giotto's frescoes. < www. sanfrancesco.org $>$

(accessed 2021, February 28).

Fig. 7. La Basilica di vetro. Reproduction of Giotto's Nativity. <www. sanfrancesco.org >

(accessed 2021, February 28)
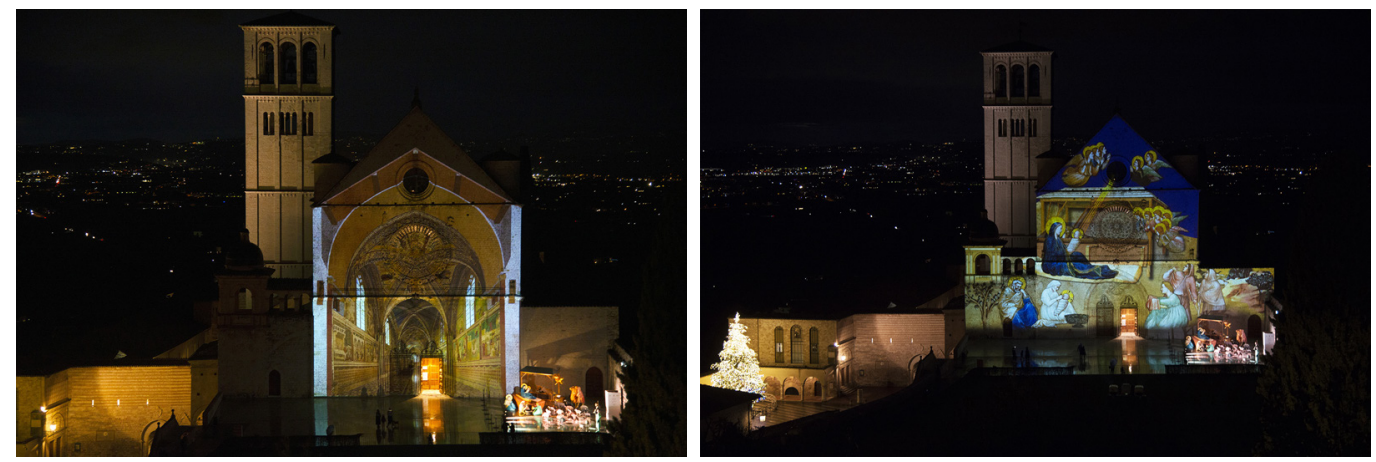

technologies suitable for outdoor use, more easily reconciled with the needs dictated by distance.

The installation involves several important monuments in Assisi, including the facade and bell tower of the Cathedral of San Rufino, affected by an architectural and scenic video mapping, which reproduces the Annunciation to Mary. The route is designed as an itinerary of luminous stars, inspired by the frescoes on the vaults of the Lower Basilica, and actually transforms Assisi into a single large light installation, visible also from the valley of Santa Maria degli Angeli. Initially conceived as a physical appointment to involve visitors from all over the world, the project has been adapted to a new formula based on virtual participation, in privileged presence for Umbrian citizens, and remotely for all those who wanted to follow the streaming of the inauguration and, later, the video reproduction via web.

The central feature of the work is the elevation of the Upper Basilica, for which Marco Capasso - Studio Creativo designed and produced the 'Glass Basilica'. The architect Capasso

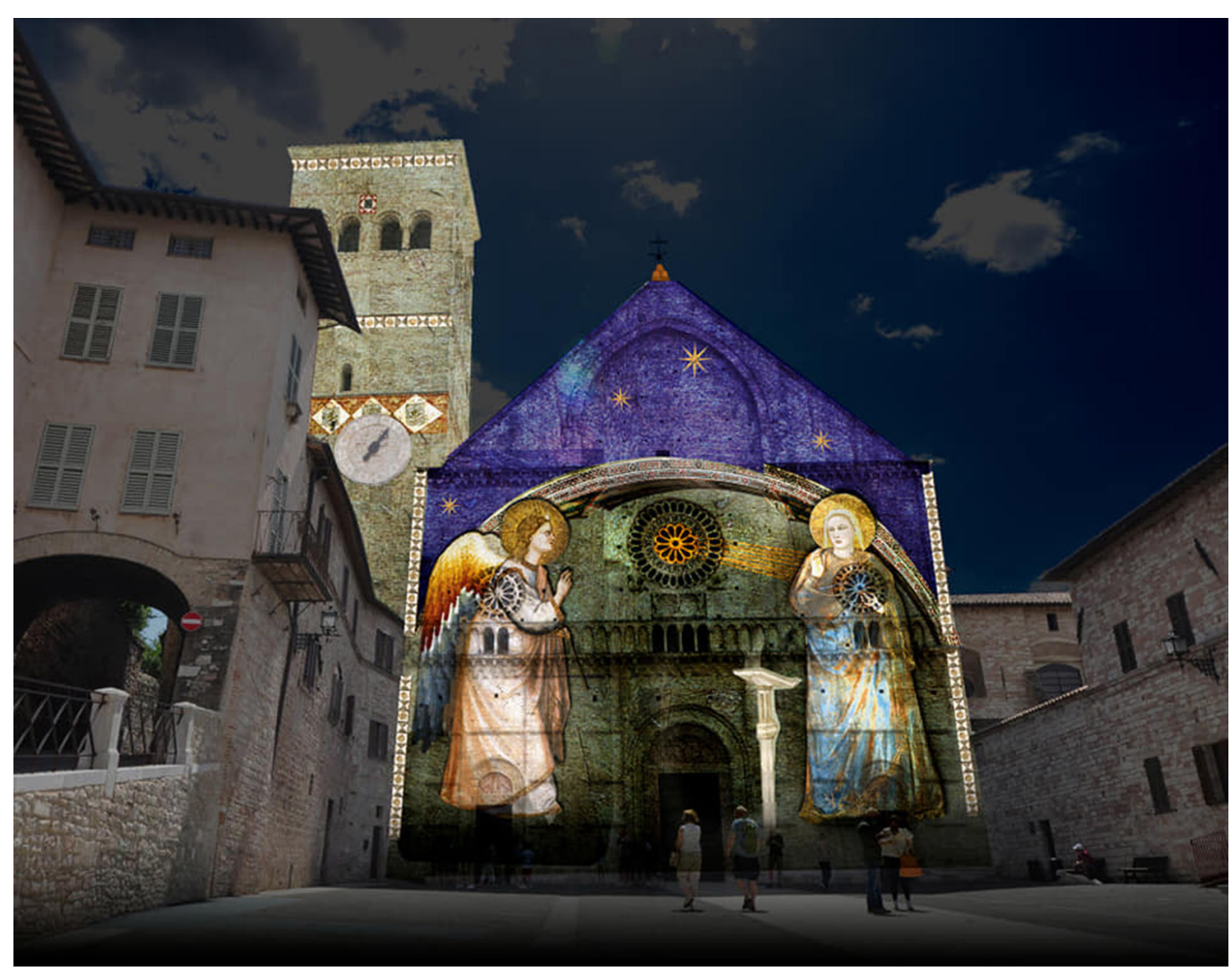

Fig. 8. Installation for the Cathedral of San Rufino reproduction of the Annunciation to Mary. <http://www.comune assisi.pg.it/2020//2/09/ natale-2020/> (accessed 2021, May 10). 
has created what he himself defines as "an installation of additive light" that opens up to a story, in whose prologue, inspired by the Canticle of the Creatures, Brother Sun and Sister Moon become the protagonists of the projection, in an animation that unfolds over the Basilica, making it almost disappear into the night sky in the background. This is followed by a sequence of images and an evocative incipit, in which light is the protagonist and shows two ancient winches in movement, representing the medieval building site that raises the scaffolding and constructs the contours of the Basilica's facade. A geometrization of space, a design of clear and essential lines, which behind the framework reproduces the facade with the portal, the cornices and the rose windows, in a white on black reproduction of extraordinary strength. Then, for a few moments, a light shows the stone facade again, with its textures and materiality, to disappear after a while, leaving space for a new representation, this time in perspective, which reveals the internal structure of the nave, defined by a single space marked by pillars and surmounted by cross vaults. This aspect shows the masterful three-dimensional reconstruction produced by architect Capasso, who has held together the 3D model and photographs (in very high resolution) of Giotto's frescoes on the interior walls. The conclusion of the projection is in fact the reproduction of Giotto's Nativity, the central theme of the whole event.

In the case of Assisi, therefore, the subject of the narration is architecture, not only in its external spaces, but also in its internal conformation, spatial and chromatic details. This digital experimentation opens up a new possibility of fruition that, under certain conditions, allows the discovery of the interior of the monuments, where they are not physically accessible, thus approaching a broad and contemporary concept of 'accessibility', which aims to reduce distances through the use of new languages.

\section{Conclusions}

The recent experiences described in this contribution show how in the field of visual communication, which today encompasses multiple expressions of design, different needs can come together, resulting in a variety of graphic solutions: in some cases there is a need to leave room for the imagination of the users and therefore the communication is allusive and seeks an emotional impact, rather than cognitive; in other cases, however, the purpose of the operation is popular and aims to make content accessible, therefore it uses a defined representation, not subject to personal interpretation. In essence, these are the conditions presented by the proposed experiments, both of which have in common the ability to create public 'stages' involving urban spaces and places of worship, creating a narrative with great emotional impact and exploiting new languages and new expressive possibilities. Technological innovations also offer a means of disseminating knowledge about cultural heritage and, in particular through video mapping, it is possible to extend the range of action, reaching different categories of users, even those less inclined to use multimedia devices and viewers. This approach, physical and digital at the same time, is becoming an added value to communication and public use, even at a distance.

\section{Acknowledgements}

I would like to thank Felice Limosani for his valuable collaboration and the passion with which he described his work to me. I thank also the architect Marco Capasso, for his willingness to tell the story of the project and to provide the material, and the Convent of San Francesco, in particular Alessio Maria Antonielli, for sharing the photographic documentation.

\section{References}

Antonelli E., Mordenti A. (20I I). La videoproiezione architetturale. Architectural Video projection. In Disegnarecon, vol. 4, n. 8, Cultural Heritage communication technology, pp. 25-38.

De Rubertis R., Clemente M. (200I). Percezione e comunicazione visiva dell'architettura. Roma: Officina Edizioni.

Di Natale I., Palmieri A. (2015). Tecno-comunicazione creativa. Proiezioni digitali per definire nuovi scenari del patrimonio culturale. In Agribusiness Paesaggio \& Ambiente on line, vol. XVIII, pp. 78-85. 
Ippoliti E. (20II). Media digitali per il godimento del patrimonio culturale. Digital Media and enjoyment of Cultural Heritage. In Disegnarecon, vol. 4, n. 8, Cultural Heritage communication technology, pp. 2-13.

Ippoliti E., Meschini A. (20 I0). Dal "modello 3D" alla "scena 3D". Prospettive e opportunità per la valorizzazione del patrimonio culturale architettonico e urbano. / From the "3D model" to the "3D scene". Prospects and opportunities for the enhancement of an architectural and urban cultural heritage. In Disegnarecon, vol. 3, n. 6, Cultural heritage documentation, pp. 77-9 I.

Maniello D. (20|4). Realtà aumentata in spazi pubblici. Tecniche base di video mapping. Potenza: Le Penseur edizioni.

Rocchi G. (1982). La basilica di San Francesco ad Assisi: interpretazione e rilievo. Firenze: Sansoni Editore.

\section{Website}

<https://www.felicelimosani.com/it/> (consultato il 10 febbraio 202I). (accessed 2021, February 10).

<https://www.felicelimosani.com/it/projects.70/il-grande-dittatore-re-work> (accessed 2021, February 10).

<https://www.marcocapasso.it/portfolio/enel-assisi-il-natale-di-francesco/> (accessed 2021, Januaryl3).

<https://www.mcarchitects.it/project/il-natale-di-francesco> (accessed 202I, Januaryl3).

$<$ https://www.sanfrancescopatronoditalia.it/notizie/eventi/assisi-citt\%C3\%A0-presepe-da-oggi-rivivono-gli-affreschi-di-giotto-50242> (accessed 2021, January 24).

<https://www.sanfrancescopatronoditalia.it/notizie/eventi/enel-illumina-assisi-con-il-natale-di-francesco-5030l> (accessed 202I, January 24).

Author

Alice Palmieri, Università della Campania ‘Luigi Vanvitelli', alice.palmieri@unicampania.it

To cite this chapter. Palmieri Alice (2021). Paesaggi urbani tra tradizione e fruizione virtuale: un viaggio tra sperimentazioni di estetica digitale/ Urban Landscapes between Tradition and Virtual Fruition: a Journey through Experiments in Digital Aesthetics. In Arena A., Arena M., Mediati D. Raffa P. (a cura di). Connettere. Un disegno per annodare e tessere. Linguaggi Distanze Tecnologie. Atti del $42^{\circ}$ Convegno Internazionale dei Docenti delle Discipline della Rappresentazione/Connecting. Drawing for weaving relationship. Languages Distances Technologies. Proceedings of the 42th International Conference of Representation Disciplines Teachers. Milano: FrancoAngeli, pp. 2535-2548. 